\title{
ANALISIS LINGKUNGAN EKSTERNAL DAN INTERNAL DALAM MENYUSUN STRATEGI PERUSAHAAN (Studi Perencanaan Strategi Komoditi Kelapa Sawit Pada PT. Perkebunan Nusantara III (Persero))
}

\author{
Dedi Septiadi Gunawan ${ }^{1)}$, Taher Alhabsji ${ }^{2}$, Kusdi Rahardjo ${ }^{3)}$ \\ ${ }^{1)}$ PT. Perkebunan Nusantara III (Persero) Medan \\ ${ }^{2,3}$ Fakultas Ilmu Administrasi Universitas Brawijaya Malang \\ Email ${ }^{1)}$ dedisg78@gmail.com
}

\begin{abstract}
The purpose of this reserach was to gain corporate level strategy for PT. Perkebunan Nusantara III that lead company becoming a champ in competition and provide a sustainable growth. The object of this research is PTPN III (Persero). This type of applied research use a quantitative approach. Method survey conducted by distributing questionnaires to the respondents as the primary data. Purposively selects respondents (purposive sampling). FDGs also conducted by five men palm oil industry players to determine the weight ang rating values on EFE, IFE, CPM, and QSPM Matrix. Secondary data were obtained from the company internal documentation and other relevant data sources. This research uses STEEPLE and Porter's Five Forces Model analysis approach to analyze the company external environment. For the Internal analysis using Value Chain analysis approach (VCA) to analyze its internal resources. Research tools used for strategy analysis are: SWOT, SPACE, BCG, IE, Grand Strategy, and QSPM Matrix. The research found that the strategy for PTPN III palm industri is Product Development Strategy and Foward Integration Strategy. Recommendations policies at the operational level that supports the selected strategies, includes: changes / additions of the company capital structure, the expansion of oil palm land area, development / downstream palm oil products that provide value-added products, and bench marking as a means of preparing HR and The best technology.
\end{abstract}

Keywords: Evaluation Strategy, EFE, IFE, CPM, SWOT, SPACE, BCG, IE, Grand Strategy, QSPM, Corporate Strategy, PTPN III.

\begin{abstract}
ABSTRAK
Penelitian ini bertujuan mendapatkan strategi tingkat korporasi PT. Perkebunan Nusantara III yang unggul dalam persaingan dan memberikan pertumbuhan perusahaan secara berkelanjutan (sustainable growth). Objek Penelitian ini adalah PTPN III. Penelitian Terapan (applied research) ini menggunakan pendekatan kuantitatif. Metode survei dilakukan melalui penyebaran kuisioner kepada responden sebagai data primer. Pemilihan responden dilakukan secara purposive ( purposive sampling). Disamping itu dilakukan FGD oleh lima orang pelaku industri kelapa sawit untuk menentukan bobot dan rating nilai pada matrik EFE, IFE, CPM, dan QSPM. Data sekunder didapat dari dokumentasi perusahaan dan sumber data terkait lainnya. Penelitian ini menggunakan pendekatan analisis STEEPLE dan Model Lima Kekuatan Porter untuk menganalisis lingkungan eksternal perusahaan. Analisis lingkungan internal perusahaan menggunakan pendekatan analisis Rantai Nilai (VCA) untuk menganalisa sumberdaya internalnya. Alat analisis strategi yang digunakan adalah Matrik: SWOT, SPACE, BCG, IE, Grand Strategy, dan QSPM. Hasil dari penelitian terapan ini didapati bahwa Strategi kelapa sawit terbaik PTPN III adalah Strategi Pengembangan Produk dan Strategi Integrasi ke Depan. Rekomendasi kebijakan-kebijakan di level operasional yang mendukung strategi terpilih, antara lain: perubahan/penambahan modal ekuitas pada struktur pemodalan perusahaan, penambahan luas areal lahan kelapa sawit, pengembangan/hilirisasi produk CPO yang memberikan nilai tambah produk, dan bench marking sebagai sarana mempersiapkan SDM dan teknologi terbaik.
\end{abstract}

Kata Kunci: Evaluasi Strategi, EFE, IFE, CPM, SWOT, SPACE, BCG, IE, Grand Strategy, QSPM, Strategi Korporasi, PTPN III 


\section{PENDAHULUAN}

Sektor industri dengan karakteristik tingkat persaingan yang ketat dan lingkungan yang dinamis, seperti sektor industri kelapa sawit, perencanaan strategis merupakan kunci dari pencapaian keunggulan bersaing dan keberhasilan sebuah perusahaan. Kemampuan perusahaan untuk mengeksploitasi sumber daya serta menciptakan peluang baru dan berbeda dengan mengoptimalkan keunggulan kompetitif yang dimiliki perusahaan merupakan jaminan keberhasilan dalam peta persaingan industri dan juga keberhasilan jangka panjang perusahaan ke depan.

Perencanaan Strategis merupakan hasil dari aktifitas perencanaan yang membedakan apakah suatu perusahaan akan menjadi perusahaan yang unggul atau menjadi perusahaan yang kehilangan daya saing. Keberhasilan suatu perencanaan strategis yang telah ditetapkan sangat ditentukan oleh seberapa besar tingkat kesesuaian strategi tersebut dengan perubahan lingkungan, persaingan, serta situasi internal organisasi sehingga mampu menciptakan keunggulan kompetitif secara berkelanjutan. Ketidakpekaan dan ketidakmampuan perusahaan dalam menganalisa dan beradaptasi dengan cepat serta tepat terhadap perubahan lingkungan internal dan eksternal yang kompetitif dapat "melumpuhkan" kinerja perusahaan yang secara perlahan dan tanpa disadari dapat menyebabkan kebangkrutan perusahaan.

Faktor harga jual CPO dan pengaruh perubahan iklim menjadi faktor eksternal penting yang menentukan margin keuntungan dan tingkat produktifitas tanaman kelapa sawit. Kedua faktor eksternal tersebut merupakan variabel lingkungan eksternal yang tidak dapat dikontrol, dimana penetapan harga jual CPO mengacu pada bursa pasar di Malaysia dan Roterdam. Sehingga, seringkali target tahunan perusahaan tidak tercapai dengan realisasi kinerja yang dihasilkan.

Permasalahan minimnya infrastruktur yang ada dan isu-isu politik terkait Pemilu Presiden RI 2014, black campaign pengaruh negatif produk CPO terhadap kesehatan dan lingkungan, persaingan industri, ancaman produk substitusi, perkembangan teknologi, perubahan budaya, pertumbuhan demografis, stabilitas perekonomian serta kebijakan yang menghambat perkembangan industri kelapa sawit dan turunannya menjadi beberapa faktor eksternal yang penting perlu dipertimbangkan sebelum menetapkan strategi bisnis kelapa sawit perusahaan. Secara internal, pemilihan strategi yang tidak efektif, aktifitas penerapan yang buruk, penetapan tujuan perusahaan yang teralu optimis, langkah korektif yang tidak tepat, penggunaan struktur pemodalan untuk pengembangan usaha merupakan faktor-faktor internal yang perlu mendapat perhatian dalam melakukan perencanaan strategis bisnis kelapa sawit PTPN III.

Bidang usaha kelapa sawit diharapkan terus berperan dalam pertumbuhan penjualan perusahaan, mengingat kontribusi laba yang dihasilkan dari bisnis kelapa sawit ini sangat besar bagi perusahaan dan memiliki prospek profit industri kedepan yang sangat menjanjikan.

Berdasarkan latar belakang di atas, maka rumusan masalah dalam penelitian ini adalah :

1. Apakah strategi bisnis kelapa sawit PTPN III saat ini masih sesuai terhadap perubahan lingkungan eksternal-internal yang dinamis dan kompetitif?

2. Faktor-faktor lingkungan eksternal dan internal apa saja yang mempengaruhi kebijakan strategis bisnis kelapa PTPN III?

3. Faktor-faktor lingkungan eksternal dan internal utama apa saja yang mempengaruhi kebijakan strategis PTPN III, yang merupakan kekuatan, kelemahan, peluang dan ancaman utama bagi bisnis kelapa sawit PTPN III?

4. Bagaimana mengembangkan hasil analisis lingkungan eksternal-internal sehingga didapatkan strategi bisnis kelapa sawit terbaik bagi PTPN III?

5. Kebijakan-kebijakan apa yang harus diambil di tahapan operasional, untuk mendukung implementasi strategi bisnis kelapa sawit PTPN III terpilih?

\section{LATAR BELAKANG TEORI DAN HIPOTESIS \\ Tinjauan Konsep Strategi \\ Definisi Manajemen Strategis}

Manajemen Strategis dapat

didefinisikan sebagai seni dan pengetahuan dalam merumuskan, mengimplementasikan, serta mengevaluasi keputusan-keputusan lintas fungsional sehingga sebuah organisasi mampu mencapai tujuannya (David, 2010). Manajemen strategis juga dapat didefinisikan sebagai suatu rangkaian keputusan dan tindakan yang menghasilkan formulasi dan implementasi 
rencana untuk mencapai tujuan perusahaan (Pearce dan Robinson, 2013). Menurut Glueck dan Jauch (1991) menyebutkan bahwa manajemen strategis adalah arus keputusan dan tindakan yang mengarah pada pengembangan strategi-strategi yang efektif untuk mencapai sasaran perusahaan. Manajemen Strategis (Menstra) mempunyai kesamaan arti dengan Perencanaan Strategis (David, 2010). Istilah Manajemen Strategis sering merujuk atau digunakan oleh kalangan akademisi, sementara dalam dunia praktisi bisnis, Perencanaan Strategis menjadi istilah yang lebih banyak dipakai.

Perencanaan strategis dihasilkan dari pilihan-pilihan manajerial yang sulit atas berbagai alternatif-alternatif terbaik yang ada dengan mempertimbangkan perubahan lingkungan (pasar, kebijakan, prosedur, tingkat persaingan, inflasi, tingkat pertumbuhan ekonomi, teknologi, demografis, dan operasi tertentu) untuk menetapkan tindakan terbaik yang paling memberikan keuntungan bagi perusahaan. Analisis terhadap perubahan lingkungan ini, walau tampak sederhana, namun memerlukan kajian dan pemahaman para manajer akan pokok persoalan yang ada, karenanya akan memberikan jawaban yang berbeda-beda antara manajer satu dengan yang lainnya, bahkan kemungkinan bertolak belakang dan pertentangan. (Collins dan Porras, 1997; Marcus, 2006; Peters dan Waterman Jr., 1982).

Upaya menetapkan strategi bisnis yang bertujuan untuk mengembangkan suatu bisnis yang memungkinkan perusahaan memperoleh keunggulan kompetitif atas pesaingnya dalam suatu pasar atau industri dijelaskan oleh beberapa landasan teori. Porter (1989), menyebutkan ada tiga strategi generik pada unit bisnis yang dapat menjadi pilihan perusahaan dari berbagai industri untuk memperoleh keunggulan kompetitif bagi bisnis perusahaan. Ketiga strategi tersebut adalah kepemimpinan biaya (cost leadership), diferensiasi (defferentiation), dan fokus (focus).

Strategi kepemimpinan biaya adalah strategi yang menawarkan produk atau jasa kepada konsumen pada harga dan nilai harga terendah, sedangkan strategi diferensiasi bertujuan menghasilkan produk atau jasa yang dianggap unik di industri. Sedangkan strategi fokus adalah strategi yang menawarkan produk atau jasa kepada sekelompok kecil konsumen yang sudah dipilih sebelumnya (segmented).
Sebuah perusahaan dikatakan memiliki keunggulan kompetitif dibanding perusahaan lainnya apabila perusahaan mampu memperoleh laba yang lebih besar secara kontinu dibandingkan pesaing.

\section{Evaluasi Strategi}

Evaluasi strategi penting dilakukan karena organisasi menghadapi lingkungan yang dinamis dimana faktor-faktor eksternal dan internal utama sering berubah dengan cepat. Evaluasi strategi meliputi tiga aktivitas pokok (David, 2010): penyelidikan atas landasan yang mendasari strategi perusahaan, perbandingan hasil yang diharapkan dengan hasil yang sebenarnya, mengambil tindakan korektif guna memastikan bahwa kinerja sesuai rencana.

Evaluasi terhadap strategi menjadi semakin sulit seiring dengan berjalannya waktu, antara lain disebabkan:

1. Meningkatnya kompleksitas lingkungan yang dinamis,

2. Semakin sulitnya untuk memprediksi masa depan secara akurat,

3. Bertambahnya jumlah variabel,

4. Cepat usangnya usia pakai produk bahkan untuk rancangan yang paling bagus sekalipun,

5. Semakin banyaknya kejadian di dalam dan luar negeri yang mempengaruhi perusahaan,

6. Berkurangnya rentan waktu untuk menjalankan perencanaan dengan derajat kepastian tertentu.

Kriteria untuk mengevaluasi strategi harus terukur dan mudah untuk diverifikasi. Kriteria yang memprediksi hasil kiranya lebih penting daripada yang menunjukan apa yang telah terjadi. Evaluasi strategi didasarkan baik pada kriteria kuantitatif maupun kualitatif. Memilih serangkaian kriteria yang pasti untuk mengevaluasi strategi bergantung pada ukuran organisasi, industri, strategi, dan filosofi manajemen. Kriteria kuantitatif yang lazim digunakan untuk mengevaluasi strategi biasanya digunakan pada kajian finansial perusahaan, sedangkan untuk kriteria kualitatif biasanya digunakan untuk mengukur kriteria yang berhubungan dengan faktor manusia, seperti tingkat kepuasan, motivasi, dan kinerja manusia.

Keuntungan melakukan aktifitas
evaluasi strategi bisa memperbaharui
kepercayaan diri pada strategi bisnis saat ini
atau menunjuk pada perlunya langkah untuk
memperbaiki kelemahan-kelemahan tertentu,


seperti terkikisnya keunggulan produk atau keunggulan teknologi. Dalam banyak kasus, keuntungan evaluasi strategi mempunyai artinya yang jauh lebih luas, sebab hasil akhir dari proses tersebut bisa jadi adalah strategi yang secara mendasar baru yang akan membawa, bahkan pada bisnis yang sudah menghasilkan, pada peningkatan yang substansial. Kemungkinan inilah yang menjustifikasi evaluasi strategi, sebab timbal baliknya bisa jadi sangat besar.

\section{Analisis Lingkungan Eksternal Perusahaan}

Dikutip dari David (2010), Duncan (1972) menjelaskan yang dimaksud dengan lingkungan eksternal perusahaan (external business environment) adalah berbagai faktor yang berada di luar organisasi yang harus diperhitungkan oleh organisasi perusahaan pada saat membuat keputusan. Lingkungan eksternal perusahaan adalah semua kejadian di luar perusahaan yang memiliki potensi untuk mempengaruhi perusahaan (Chuck Williams, 2001:51). Pearce II dan Robinson (2013) mendefinisikan lingkungan eksternal merupakan faktor-faktor diluar kendali yang mempengaruhi pilihan perusahaan mengenai arah dan tindakan, yang pada akhirnya juga mempengaruhi struktur organisasi dan proses internalnya.

Hermawan kartajaya

menyebutkan kondisi persaingan saat ini berada pada tahap wild, dimana perusahaanperusahaan yang bersaing dalam satu industri bahkan lintas lindustri, memiliki akses yang relatif sama terhadap ketersediaan teknologi untuk menghasilkan produk baru. Sementara itu, Fitzroy dan Hulbert (2005: 6) menggambarkan lingkungan perusahaan saat ini sebagai sebuah turbulen world, dunia yang dipenuhi dengan perubahan dan sulit untuk dipolakan. Dalam keadaan seperti ini, berbagai perubahan berjalan begitu cepat dan tidak selalu dapat diprediksi dengan akurat.

Analisis lingkungan eksternal perlu dilakukan untuk mengidentifikasi peluangpeluang dan ancaman-ancaman besar yang dihadapi suatu organisasi terhadap perubahan lingkungan eksternal perusahaan sehingga manajer dapat merumuskan strategi guna mengambil keuntungan dari berbagai peluang tersebut dan menghindar atau meminimalkan dampak dari ancaman potensial yang muncul. David (2010: 120), mengatakan faktor-faktor kekuatan eksternal utama (external force) dalam melakukan analisis lingkungan eksternal dapat dibagi menjadi lima kategori : (1) kekuatan ekonomi, (2) kekuatan sosial, (3) kekuatan politik, (4) kekuatan teknologi, dan (5) kekuatan kompetitif. Kelima kategori ini memiliki elemen penting yang harus dipertimbangkan oleh pembuat keputusan strategi dalam menganalisa lingkungan eksternal perusahaan.

\section{Analisis Lingkungan Internal Perusahaan}

Lingkungan internal adalah lingkungan organisasi yang berada di dalam organisasi tersebut dan secara normal memiliki implikasi yang langsung dan khusus pada perusahaan. Analisis lingkungan internal perusahaan didefinisikan sebagai suatu proses perencanaan strategi yang mengkaji bidang pemasaran, dan distribusi perusahaan, penelitian dan pengembangan, produksi dan operasi, sumber daya dan karyawan perusahaan, serta faktor keuangan dan akuntansi untuk menganalisa kekuatan dan kelemahan dari masing-masing divisi tersebut sehingga perusahaan dapat memanfaatkan peluang dengan cara yang paling efektif dan dapat menangani ancaman (Lawrence dan Wiliam, 1998),

Analisis terhadap lingkungan internal perusahaan bertujuan untuk mengidentifikasi sejumlah kekuatan dan kelemahan yang terdapat pada sumber daya dan proses bisnis internal yang dimiliki perusahaan. Sumber daya dan proses bisnis internal dikatakan memiliki kekuatan apabila sumber daya dan proses bisnis internal tersebut memiliki kemampuan (capability) yang akan menciptakan distinctive competencies sehingga perusahaan akan memperoleh keunggulan kompetitif. Beberapa analisis yang digunakan untuk mengukur kemampuan sumber daya internal perusahaan, antara lain : Analisis SWOT (Strength, Weakness, Oppotunities, Threat) dan analisis rantai nilai (value chain analysis) dan pandangan berbasis sumber daya (resource base view - RBV). Masing-masing alat analisis memiliki kelebihan dan kelemahan dalam melakukan analisas lingkungan internal perusahaan.

\section{Pertumbuhan Perusahaan Berkelanjutan}

Pertumbuhan perusahaan secara berkelanjutan adalah upaya-upaya strategis perusahaan dalam menciptakan distinctive competencies guna memperoleh keunggulan kompetitif serta mempertahankan pertumbuhan 
jangka panjang perusahaan. Day \& Wensley (1988) menyatakan bahwa keunggulan bersaing berkelanjutan merupakan bentuk-bentuk strategi untuk membantu perusahaan dalam mempertahankan kelangsungan hidupnya. Ferdinand (2003) menyatakan bahwa pada pasar yang bersaing, kemampuan perusahaan menghasilkan kinerja, terutama kinerja keuangan, sangat bergantung pada derajad keunggulan kompetitifnya. Kemampuan kompetitif yang unggul yang dimiliki perusahaan dapat menjamin keberlanjutan (sustainable) pertumbuhan perusahaan dalam peta persaing industri yang terus berubah.

Berdasarkan teori berbasis sumber daya (resource based theory), Barney (1995) mendefinisikan pengertian keunggulan bersaing berkelanjutan, yaitu keunggulan yang dicapai secara terus menerus dengan mengimplementasikan strategi pencapaian nilai-nilai unik yang tidak dimiliki pesaing. Sedangkan untuk melanggengkan keunggulan bersaing tersebut, perusahaan seharusnya memiliki sumber daya dan kapabilitas yang khas (company specific) (Ferdinand, 2003). Perusahaan dikatakan memiliki keunggulan kompetitif jika sumber daya yang dimilikinya memiliki empat atribut, yaitu : Kelangkaan, nilai, tidak dapat ditiru, dan tidak dapat diganti.

\section{Kerangka Konseptual Tugas Akhir}

Kerangka konseptual Tugas Akhir (TA) penulis diperlihatkan pada gambar 3.1 dibawah ini.

Kerangka konseptual tugas akhir penyusunan Strategi Bisnis Kelapa Sawit PTPN III dijabarkan pada langkah-langkah sebagai berikut: melakukan penilaian visi -misi perusahaan saat ini, mengembangkan pernyataan visi-misi kedalam Tujuan Perusahaan, mengevaluasi strategi saat ini, mengidentifikasi berbagai peluang dan ancaman eksternal perusahaan. mengembangkan Matriks Profil Kompetitif (CPM), mengembangkan Matriks Evaluasi Faktor Ekternal (EFE), mengidentifikasi berbagai kekuatan dan kelemahan internal perusahaan. Melakukan analisa keuangan perusahaan, mengembangkan Matriks Evaluasi Faktor Internal (IFE), Evaluasi dan Rekomendasi tujuan dan kebijakan perusahaan yang spesifik, mengembangkan matriks SWOT, SPACE, BCG, IE, Grand Strategy dan QSPM, rekomendasi penerapan strategi terpilih.

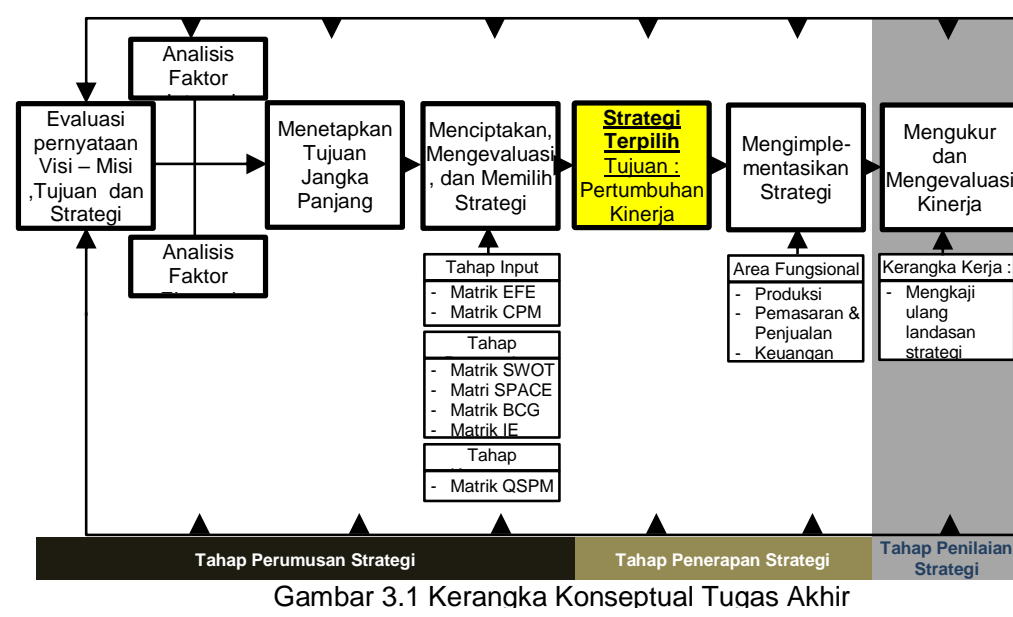

\section{METODE PENELITIAN \\ Pendekatan Perencanaan Strategi}

Penelitian Terapan (applied research) ini menggunakan pendekatan kuantitatif dengan metode survei melalui penyebaran kuisioner secara purposive sampling dan keterlibatan pelaku industri dalam suatu kelompok diskusi (Focus Discussion Group - FGD). Penelitian terapan ini menggunakan pendekatan analisa lingkungan umum (makro industri) dan pendekatan analisa struktur industri (mikro industri) dengan alat analisis STEEPLE (Social, Technological, Economics, Environmental, Political, Legal, Ethical) dan alat analisis kompetitif Model Lima Kekuatan Porter untuk menganalisa lingkungan eksternal perusahaan. Sedangkan untuk analisis lingkungan internal dilakukan melalui pendekatan analisis Rantai Nilai (Value Chain Analysis - VCA) untuk menganalisa kemampuan sumberdaya internal perusahaan.

Metode kuisioner sebagai data primer, sedangkan data analisis time series dan cross sectional digunakan sebagai data sekundernya. Untuk analisis perbandingan, penulis membatasi analisa tersebut pada 5 (Lima) perusahaan Kelapa Sawit Besar Nasional yang memiliki reputasi sebagai perusahaan besar dengan ukuran kinerja finansial dan luasan areal yang dimiliki di Indonesia. Data sekunder diperoleh dari Laporan Tahunan (Annual Report) masing-masing perusahaan, Badan Pusat Statistik (BPS) tahun 2013, dan berbagai sumber lainnya yang dinilai mempunyai keterkaitan informasi atau data yang dibutuhkan dengan penelitian terapan yang dilakukan.

Objek penelitian terapan ini adalah PTPN III. Sedangkan 4 (empat) perusahaan perkebunan kelapa sawit pesaing yang digunakan sebagai perusahaan pembanding, 
dipilih secara purposive (berdasarkan kriteria tertentu dan Focus Discussion Group-FGD) dengan kriteria:

1. Terdata pada buku direktori Perusahaan Perkebunan Kelapa Sawit Indonesia Tahun 2013 yang diterbitkan oleh BPS.

2. Tersedia data laporan keuangan selama kurun waktu 2009 - 2013.

3. Perusahaan menerbitkan laporan terkait sumberdaya-sumberdaya internal perusahaan lainnya.

4. Hasil wawancara dengan pelaku bisnis dan kelompok diskusi (FGD) yang terdiri dari 4 (empat) personil yang dianggap mempunyai pengalaman dan kompetensi di bidang bisnis perkebunan kelapa sawit PTPN III.

\section{HASIL DAN PEMBAHASAN \\ Perencanaan Strategi Bisnis Ptpn Iii Penilaian Visi-Misi PTPN III}

Visi harus memiliki dua komponen pokok, yakni Ideologi Inti (Core Ideology) dan Rancangan Masa Depan (Envisioned Future) (Collins dan Porras, 1996: 66; 1997: 220-1)). Pernyataan Visi PTPN III saat ini belum menyertakan rentan waktu yang ingin dicapai sebagai "Perusahaan agribisnis kelas dunia". Penyertaan rentan waktu ini penting untuk menggambarkan kondisi dan situasi saat ini serta upaya-upaya yang perlu dilakukan perusahaan dalam mengelola sumberdaya yang dimilikinya untuk menciptakan keunggulan kompetitif dalam memenangkan persaingan. Sehingga, hasil penilaian Visi PTPN III dinyatakan sebagai berikut:

\section{"Menjadi perusahaan agribisnis kelas dunia pada tahun 2019 dengan kinerja prima dan melaksanakan tata kelola bisnis terbaik"}

Penilaian pernyataan Misi PTPN III dilakukankan dengan pendekatan teori yang disampaikan oleh Fred R. David (2010:102) dalam bukunya yang berjudul Manajemen Strategis Konsep. David (2010: 102) menyebutkan terdapat sembilan karakteristik yang harus terangkum dalam suatu Misi perusahaan, antara lain : (1) pelanggan, (2) produk atau jasa, (3) pasar, (4) teknologi, (5) fokus pada kelangsungan hidup, pertumbuhan, dan profitabilitas, (6) filosofi, (7) konsep diri, (8) fokus pada citra publik, (9) fokus pada karyawan.

Penilaian Misi PTPN III saat ini belum mencakup komponen karakteristik: (1) pelanggan, (3) pasar, (4) teknologi, (6) filosofi, dan (7) konsep diri. Beberapa poin karakteristik tambahan dalam pernyataan Misi diperlukan untuk mendapatkan kesesuaian dengan perubahan lingkungan eksternal dan keunggulan dalam persaingan industri saat ini.

\section{Evaluasi Existing Strategi PTPN III}

Evaluasi terhadap 7 (Tujuh) strategi PTPN III dilakukan berdasarkan kriteria Ricard Rumelt (1980) untuk mengetahui tingkat/derajat penyimpangan strategi. Dari hasil evaluasi strategi berdasarkan empat kriteria Rumelt, penulis membuat Tabel 1 berupa matrik evaluasi strategi untuk menilai strategi PTPN III saat ini.

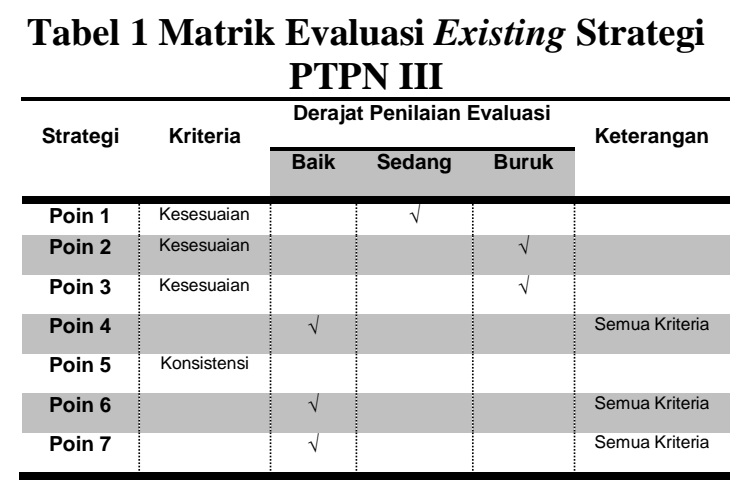

\section{Penilaian Tujuan PTPN III}

Hasil kajian terhadap Visi-Misi perusahaan dan kajian finansialnya menyimpulkan beberapa tujuan tahunan perusahaan perlu disesuaikan dengan kondisi dan situasi saat ini sehingga dapat dijadikan pedoman tindakan maupun legitimasi bagi para pengambil kebijakan dalam merancang aktivitas pekerjaan dan menetapkan keputusan yang konsisten dan terarah sehingga potensi konflik yang mungkin muncul pada saat penerapan dapat diminimalisir.

Rekomendasi tujuan Jangka Panjang yang diusulkan penulis dijabarkan sebagai berikut :

(1). Fokus pada perencanaan dan pengembangan komoditi kelapa sawit melalui peningkatan anggaran dan investasi untuk melakukan pengembangan areal lahan kelapa sawit serta menjalin kerjasama penelitian dan pengembangan antara pemerintah, swasta dan termasuk perguruan tinggi guna menghasilkan produk unggulan di pasar kompetitif.

(2). Pengembangan industri hilir kelapa sawit dalam meningkatkan nilai tambah produk 
kelapa sawit terkait dengan Pembangunan Klaster Industri Sei Mangkei (KISM) PTPN III, yang didukung dengan kelengkapan jaringan infrastruktur secara terintegrasi, baik didalam klaster maupun dengan infrastruktur nasional.

(3). Melakukan upaya-upaya strategis terhadap optimalisasi keuntungan finansial terbaik terkait struktur pemodalan untuk aktifitas investasi perusahaan.

(4). Penguatan legal aspek dan perizinan terkait dengan pembangunan kelapa sawit berkelanjutan guna memberikan kepastian pengembangan usaha dan investasi.

(5). Optimalisasi pemanfaatan Teknologi Informasi (IT) untuk kegiatan promosi, advokasi dan pemberian informasi serta pengembangan citra prositif perusahaan kepada para stakeholder dan shareholder dengan tingkat kemudahan aksesibilitas dan penggunaan.

(6). Mengiatkan aktivitas Promosi dan Advokasi dalam menanggapi kampanye hitam (black campaign) terhadap produk CPO eksport dan turunannya dengan RSPO (Roundtable on Sustainable Palm Oil) sebagai alat promosi, advokasi dan kampanye publik.

\section{Eksternal Factors Evaluation (EFE)}

Dari hasil sebaran kuisioner terhadap dilakukan, didapatkan 29 faktor lingkungan eksternal yang mempengaruhi kebijakan strategis perusahaan. Focus Discussion Group dilakukan untuk memilih 10 faktor-faktor eksternal utama yang menjadi (Opportunities) dan Ancaman (Threats) bagi perusahaan dalam bentuk Matriks Eksternal Factors Evaluation (EFE). Hasil Matriks EFE diatas, diperoleh skor bobot total Matrik EFE PTPN III sebesar 2,822. Angka ini mengindikasikan bahwa perusahaan merespon dengan baik peluang dan ancaman dalam industri kelapa sawit. Dengan kata lain, industri kelapa sawit PTPN III mampu menarik keuntungan dari peluang yang ada dan meminimalkan pengaruh negatif potensial dari ancaman eksternal.

\section{Competitive Profiling Matrix (CPM)}

Matrik ini membandingkan PTPN III dengan pesaingnya. Perusahaan pesaing yang dipilih merupakan perusahaan perkebunan kelapa sawit besar nasional, keempat perusahaan tersebut adalah : PT Perkebunan Nusantara IV/PTPN IV (Persero), PT Astra
Agro Lestari Tbk. (PT AALI), PT Sinar Mas Resources and Technology Tbk. (PT SMART), dan PT London Sumatera Tbk (PT Lonsum). Data yang digunakan adalah Annual Report Tahun 2012 untuk masing-masing perusahaan dan sumber-sumber data lainnya.

Hasil perbandingan Matrik Profil Kompetitif (CPM) didapat PTPN III memiliki total bobot skor 3,17 (rata-rata industri 3,15) berada di bawah skor PT AALI Tbk. dan PT Smart Tbk., dimana PT AALI Tbk. memperoleh total skor nilai 3,50 tertinggi di antara pesaingpesaingnya. Analisa Matrik CPM PTPN III (Tabel 2) memperlihatkan perusahaan terlihat unggul dalam pencapaian produktifitas kinerja tanaman dan pabrik, tingkat gaji, tunjangan dan bonus karyawan, serta fokus pengembangan SDM.

Tabel 2 Competitive Profiling Matrix PTPN

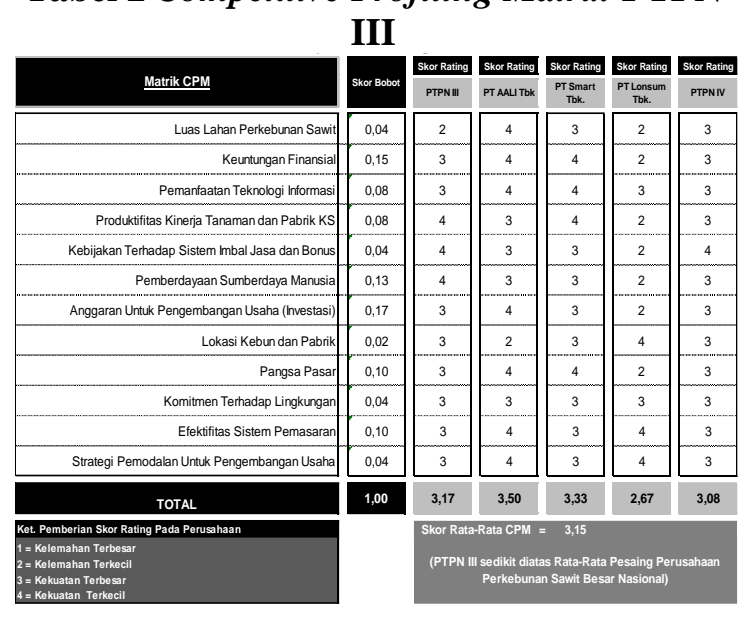

Internal Factors Evaluation (IFE)

Dari hasil sebaran kuisioner terhadap dilakukan, didapatkan 23 faktor lingkungan internal yang menjadi Kekuatan (Strength) dan Kelemahan (Weakness) dan mempengaruhi kebijakan strategis perusahaan. Focus Discussion Group dilakukan untuk memilih 10 faktor-faktor internal utama yang menjadi Kekuatan (Strength) dan Kelemahan (Weakness) bagi perusahaan dalam bentuk Matriks Internal Factors Evaluation (IFE). Hasil nilai matrik IFE PTPN III adalah 2,762. Skor bobot total PTPN III berada diatas skor rata-rata $(2,50)$, hal mengindikasikan bahwa perusahaan memiliki kemampuan Internal yang kuat dan keleluasan untuk melakukan berbagai modifikasi, inovasi terhadap sumberdaya internal yang dimilikinya dalam menghasilkan peningkatan kinerja operasional dan 
pertumbuhan perusahaan secara berkelanjutan ke depan.

\section{Matrik SWOT}

Dari kajian menggunakan matrik SWOT, terhadap lingkungan eksternal-internal PTPN III didapat beberapa strategi alternatif, sebagaimana diperlihatkan pada Tabel 3 Matrik SWOT PTPN III dibawah ini.

Tabel 3. Matrik SWOT PTPN III

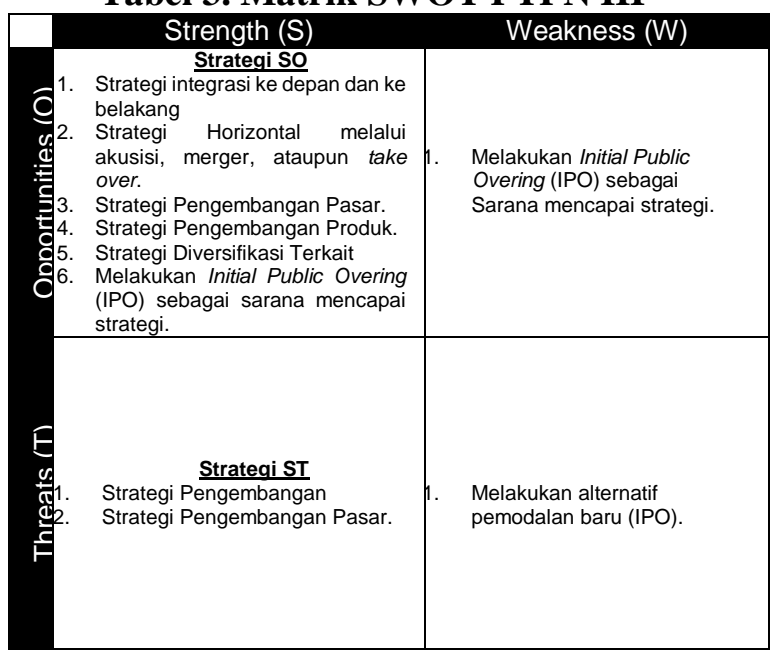

\section{Matriks Strategic Position and Action Evaluation (SPACE)}

Hasil dari matrik SPACE didapati, posisi PTPN III berada pada Agressive Quadrant (kuadran kanan atas), sehingga dapat diartikan PTPN III merupakan perusahaan yang kuat secara finansial dan memiliki keunggulan kompetitif besar di industri kelapa sawit. Beberapa strategi yang tepat yang bisa dipilih oleh PTPN III adalah melakukan strategi penetrasi pasar, pengembangan produk, integrasi ke belakang, integrasi ke depan, integrasi horizontal, pengembangan pasar, diversifikasi, maupun kombinasi dari beberapa strategi tersebut. Matrik SPACE PTPN III diperlihatkan pada Gambar 5.3 dibawah ini.

\section{Matrik Boston Consulting Group (BCG)}

Hasil matrik BCG untuk produk kelapa sawit PTPN III adalah $(0,03 ; 6,88)$ dengan persentase laba dan pendapatan adalah $86 \%$ dan $80 \%$ dari total laba dan pendapatan perusahaan.

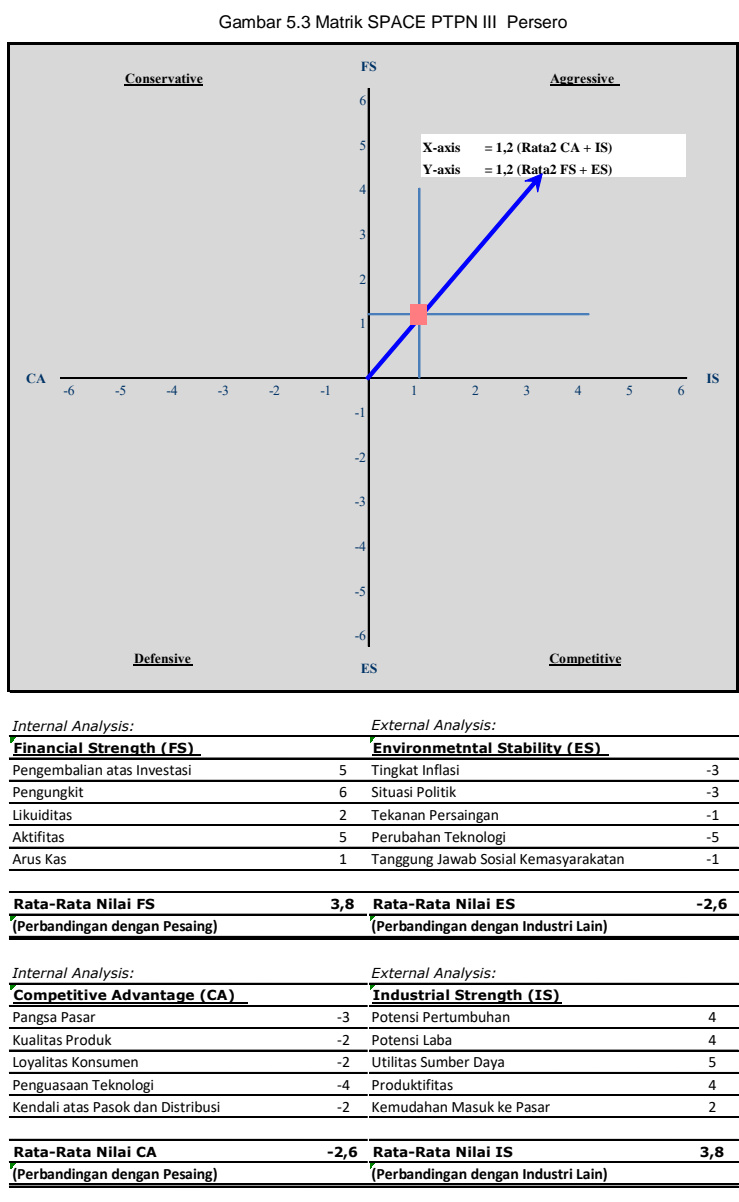

Segmen kelapa sawit memperlihatkan prospek pertumbuhan bisnis yang menjanjikan dengan tingkat pertumbuhan rata-rata cukup tinggi. Sedangkan untuk produk karet posisi di matrik BGC adalah $(0,01 ;-1,48)$ dengan persentase laba dan penjualan $14 \%$ dan $20 \%$, dan tingkat pertumbuhan bisnis ini semakin melemah.

Berdasarkan letak matriks BCG di bawah ini (Gambar 5.4), bahwa produk kelapa sawit PTPN III terletak pada kuadran Question Mark dimana pangsa pasar yang dikuasai PTPN III saat ini sangat rendah namun sesungguhnya industri ini memiliki potensi pangsa pasar yang sangat besar, dan memiliki tingkat pertumbuhan industri yang tinggi. Pada posisi ini adapun strategi alternatif yang bisa dipilih oleh PTPN III antara lain: Penetrasi Pasar.dan Pengembangan Usaha (Pasar dan Produk). 


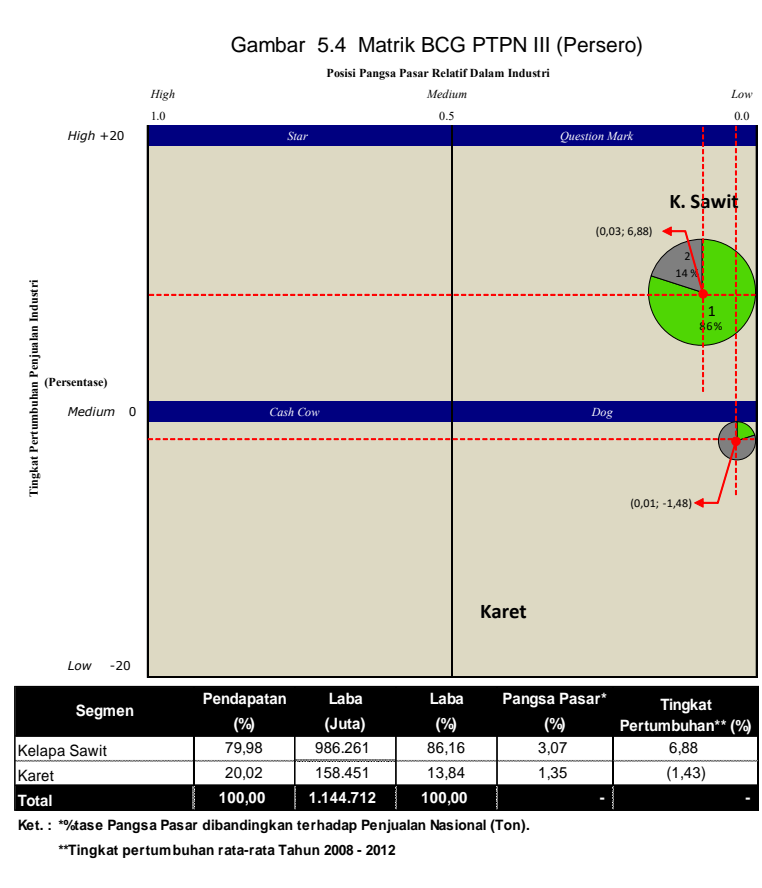

\section{Matrik Internal-Eksternal (Matrik IE)}

Hasil dari Matrik EI didapati posisi PTPN III untuk segmen komoditi kelapa sawit berada sel V (lima), maka strategi yang tepat dilakukan adalah melalui strategi menjaga dan mempertahankan (Hold and Maintain). Strategi Hold and Maintain ini dapat dilakukan melalui penetrasi pasar dan pengembangan produk. Matrik IE PTPN III diperlihatkan pada Gambar 5.5 dibawah ini.

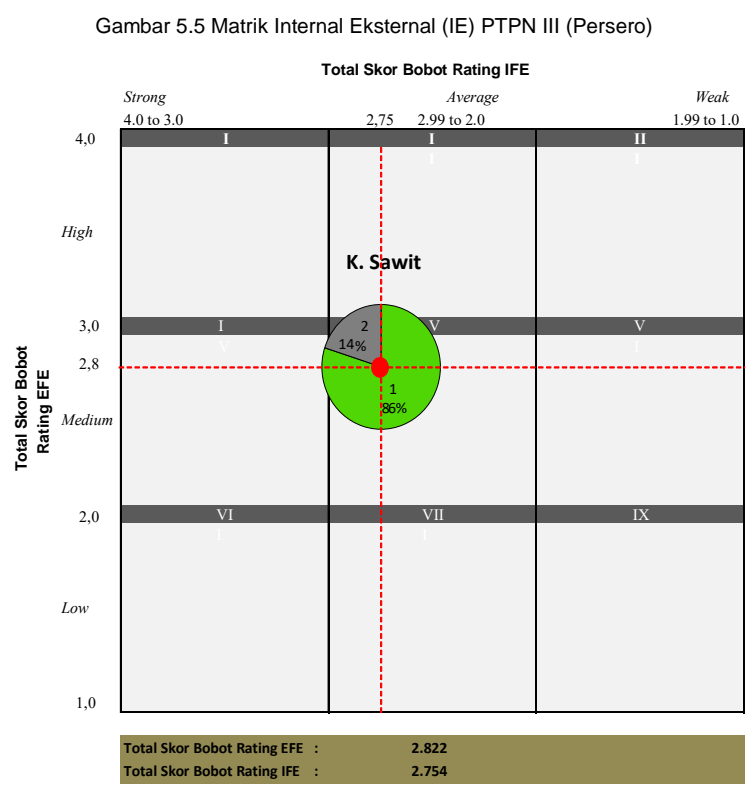

\section{Matrik Strategi Besar (Grand Strategy Matrix)}

Hasil Matrik Strategi Besar didapati posisi PTPN III berada di kuadran I. Strategi yang tepat untuk dilakukan perusahaan adalah penetrasi pasar serta pengembangan pasar dan produk. Pembangunan kawasan Sei Mangkei dan moratorium pembatasan lahan perlu direspon positif untuk mengembangkan industri hilir berbasis kelapa sawit..

\section{Quantitative Strategic Planning Matrix (QSPM)}

Dari hasil analisis tahap pencocokan dengan 5 (lima) alat pencocokan strategi (Matrik: SWOT, SPACE, BCG, IE, Grand Strategy) didapat 7 (tujuh) alternatif strategi PTPN III. Strategi terbaik berdasarkan Matrik QSPM adalah strategi pengembangan produk dengan skor nilai sebesar 1,924 dan diikuti dengan strategi integrasi kedepan dengan nilai 1,458 (Tabel 4)

Tabel 4 Matriks QSPM Untuk Strategi Alternatif PTPN III

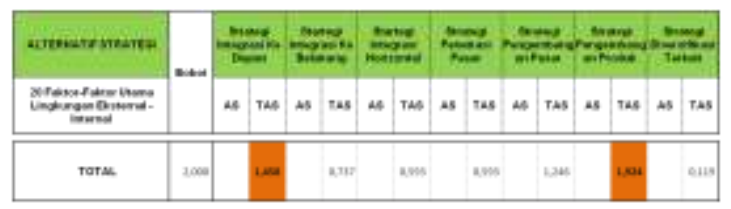

Dari matrik QSPM diatas didapat

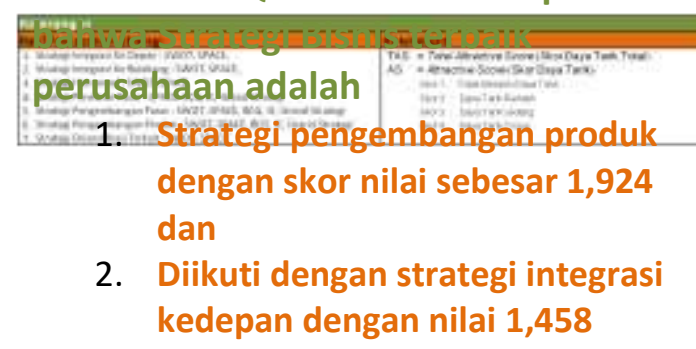

\section{KESIMPULAN DAN SARAN Kesimpulan}

Hasil dari analisa dan pembahasan yang telah dilakukan, didapati beberapa kesimpulan, antara lain:

1. Faktor utama yang menjadi Peluang (Opportunities) utama bagi perusahaan adalah : "PP nomor 29/2012 tentang penetapan Kawasan Ekonomi Khusus (KEK) Sei Mangkei milik PTPN III sebagai program nasional melalui MP3EI sebagai pusat pengembangan industri hilir berbasis kelapa sawit di Sumatera Utara dan 
didukung dengan kelengkapan infrastruktur lainnya".

2. Faktor utama yang merupakan Ancaman (Threats) utama bagi perusahaan adalah: "Penggarapan lahan oleh rakyat. Sengketa, konflik dan perkara pertanahan selalu menjadi permasalahan yang terus terjadi dan bahkan cenderung terus meningkat baik intensitas maupun keragamannya. Perkembangan populasi masyarakat kota yang makin meluas ke daerah, ketidakjelasan terhadap klaim kepemilikan atas tanah, dan kenaikkan harga tanah yang terus meningkat menjadi beberapa penyebab terjadinya penggarapan lahan perkebunan".

3. Faktor utama yang merupakan Kekuatan (Strengths) utama bagi perusahaan adalah: "Produktifitas kinerja mesin/peralatan pabrik yang dimiliki perusahaan sangat baik. Dari data jam stagnasi peralatan pabrik (PKS), persentase jam stagnasi ratarata 11 (sebelas) PKS yang dimiliki PTPN III hanya sebesar 1,32\%".

4. Faktor utama yang merupakan Kelemahan (Weakness) utama bagi perusahaan adalah : "Minimnya pilihan alternatif sumber pendaanan investasi untuk pengembangan usaha perusahaan, dimana sumber pendanaan terbesar saat ini diperoleh dari pinjaman bank berupa fasilitas kredit investasi (KI) sebesar 61,55 \% dengan tingkat bunga mengambang $7,75 \%$ - 10,25\% per tahun. Penggunaan dana investasi dari pinjaman utang bank menyebabkan cost of capital lebih tinggi jika dibandingkan didanai dengan modal sendiri (ekuitas) akibatnya efisiensi pengelolaan usaha menjadi tidak efektif sehingga margin laba perusahan menjadi lebih kecil".

5. Hasil analisis dan perhitungan menggunakan Matrik Perencanaan Strategis Kuantitatif (Quantitative Strategic Planning Matrix QSPM) terhadap pilihan-pilihan alternatif strategi dari Matrik SWOT, SPACE, BCG, IE, dan Matrik Grand Strategy, didapat bahwa strategi terbaik perusahaan jika dilihat dari perolehan skor tertinggi adalah strategi pengembangan produk dengan skor nilai sebesar 1,924 dan diikuti dengan strategi integrasi kedepan dengan nilai 1,458 .

\section{Saran}

Beberapa saran dapat direkomendasikan kepada PTPN III,antara lain:

1. Dari hasil analisis lingkungan EksternalInternal perusahaan terhadap strategi PTPN III saat ini, maka strategi tingkat korporat terbaik perusahaan adalah strategi integrasi kedepan dan strategi bisnis kelapa sawit terbaik PTPN III adalah strategi pengembangan produk.

2. Guna penerapan strategi terpilih, beberapa rekomendasi kebijakan strategi operasional yang dapat dilakukan antara lain:

(a) Bagian Produksi. Upaya yang perlu dilakukan adalah meningkatkan produksi buah kelapa sawit melalui pengembangan areal kelapa sawit. Upaya ini dapat dilakukan dengan cara membeli lahan rakyat, akusisi perusahaan, kerjasama operasi (KSO), dan konversi lahan tanaman karet ke kelapa sawit milik PTPN III.

(b) Bagian Pemasaran dan Penjualan. Mencari pasar dan pelanggan baru dan melakukan pemasaran dan penjualan langsung (direct trading) produk $\mathrm{CPO}$ kepada calon pembeli, baik yang sudah terdaftar sebagai pelanggan perusahaan maupun pembeli baru, guna mendapatkan tingkat keuntungan penjualan (margin laba) yang optimal. Serta melakukan monitoring setiap saat terhadap fluktuasi pergerakan harga CPO untuk menentukan kebijakan penjualan CPO ke pasar lokal atau eksport guna mendapatkan harga penjualan CPO tertinggi.

(c) Bagian keuangan, isu penting yang harus diperhatikan adalah kebijakan struktur pemodalan perusahaan. Saat ini struktur pemodalan perusahaan, dilihat dari Debt to Equity Ratio (DER), adalah $56,38 \%: 43,62 \%$. Kebijakan komposisi struktur pemodalan saat ini perlu diubah dengan memaksimalkan modal sendiri (equity) dengan mempertimbangkan kebijakan pembagian laba (persentase deviden dan laba ditahan), pertumbuhan aset, dan pertumbuhan penjualan perusahaan. Selain itu, melakukan kajian dan pertimbangan untuk mencari alternatif struktur pemodalan baru dari dana masyarakat melalui program Privatisasi atau Go Public (IPO) dengan 
memberikan kesempatan kepemilikan saham oleh karyawan seluas-luasnya (ESOP).

(d) Bagian Sumber Daya Manusia. Agar proses implementasi strategi terpilih dapat optimal, maka diperlukan pemberian informasi dan sosialisasi yang jelas dan kontinyu tentang visi, misi, tujuan yang ditetapkan dan strategi yang ingin dilakukan kepada semua bagian diinternal perusahaan serta mengajak keterlibatan semua pihak secara aktif. Hal ini penting dilakukan untuk mengurangi resistensi dan menciptakan kondisi yang kondusif terhadap perubahan tersebut.

(e) Bagian Pengkajian dan Pengembangan. Melakukan program bench marking dengan perusahaan-perusahaan terkemuka dan handal untuk mengembangkan produk hilir CPO guna mendapatkan proses transfer pengetahuan dan teknologi baru di industri hilir CPO serta untuk menekan resiko kerugian finansial yang timbul akibat implementasi kebijakan strategis ini.

Dengan penerapan strategi integrasi kedepan dan strategi pengembangan produk CPO (hilirisasi produk CPO) melalui pembangunan Pabrik Minyak Goreng, PTPN III mampu meningkatkan nilai penjualannya sebesar 6,5 persen setiap tahunnya, mempertahankan tingkat likuiditas perusahaan dengan baik, memberikan jaminan stabilitas harga jual dan serapan volume produksi CPO, mengurangi beban biaya produksi serta memberikan nilai tambah produk yang berlipat bagi perusahaan.

\section{DAFTAR PUSTAKA}

Adisaputro, Gunawan dan Asri, Marwan (2011). Anggaran Perusahaan, Buku 1, Edisi 2. Yogyakarta. BPFE-Yogyakarta

Barney, J.B. (1995). Looking Inside for Competitive Advantage. Academy of Management Executive. Vol. 9

Bayles, Carter. (1977), Strategic Control: The President's Paradox," Business Horizons 20.

Collins, James C., dan Jerry L. Porras. (1997) Building to Last: Successful Habits of
Visionary Company. New York. Harper Business.

Deptan, 2012. Potensi luas lahan perkebunan di Indonesia

Data Pusat Infosawit (2010), Perbandingan Luas Area Tanaman Penghasil Minyak Nabati di Dunia

David, Fred R. (2010). Manajemen Strategis Konsep, Buku 1, Edisi 12. Jakarta. Salemba Empat.

David, Fred R. (2009). Manajemen Strategis Kasus, Buku 2, Edisi 12. Jakarta. Salemba Empat.

Duncan, R.B. (1972). Characteristics of Organizational Environments and Precieved Environmental Uncertainty. Administrative Science Quaterly, Vol. 17.

Fahmi, Irham (2012). Analisis Kinerja Keuangan : Panduan Bagi Akademisi, Manajer, dan Investor Untuk Menilai dan Menganalisa Bisnis dari Aspek Keuangan. Bandung. Alfabeta.

Ferdinand, Augusty (2000). Struktural Equation Modelling dalam Penelitian Manajemen. Emarang. Program Magister Manajemen Universitas Diponegoro.

Fitzroy, P., dan Hulbert, J. (2005). Strategiy Management: Creating Value in Turbulent Times. Jhon Wiley.

Glueck, William dan Jauch, Lawrence (1991). Manajemen Strategis dan Kebijakan Perusahaan, Edisi 3. Jakarta. Erlangga.

Hunger, J. David dan Wheelen, Thomas L. (2003). Manajemen Strategis, Edisi 2. Yogyakarta. ANDI.

Irawam, Parahita (2012). Street Investing 1st ed. Jakarta W \& G Wealth \& Grow.

Jurnal Penelitian STIPAP, 2013

Laporan Keuangan Konsulidasian 2013 PTPN III. Medan. PT Perkebunan Nusantara III.

Laporan Tahunan 2013 PT Astra Agro Le 165 Tbk. Jakarta. PT Astra Agro L€ Tbk. 
Laporan Tahunan 2013 PT Bakrie Sumatera Plantation Tbk. Jakarta. PT Bakrie Sumatera Plantation.

Laporan Tahunan 2009 PTPN III. Medan. PT Perkebunan Nusantara III.

Laporan Tahunan 2010 PTPN III. Medan. PT Perkebunan Nusantara III.

Laporan Tahunan 2011 PTPN III. Medan. PT Perkebunan Nusantara III.

Laporan Tahunan 2012 PTPN III. Medan. PT Perkebunan Nusantara III.

Laporan Tahunan 2013 PTPN IV. Medan PT Perkebunan Nusantara IV. 158

Laporan Tahunan 2013 PT Smart Tbk. Janaı ı. PT Smart Tbk.

Marcus, Alfred A. (2006). Big Winner and Big Loosers: The 4 Secrets of Long Term Business Success and Failure. Upper Saddle River. Wharton School Publishing.

Muhammad, Suwarsono (2013). Manajemen Staregik : Konsep dan Alat Analisis, Edisi 5. Yogyakarta. STIM YKPM.

Pearce II, Jhon A. \& Robinson Jr, Richard B. (2013). Manajemen Strategis : Formulasi, Implementasi, dan Pengendalian, Buku 1, Edisi 12. Jakarta. Salemba Empat.

Porter, Michael E.(1989). Competitive Strategy. New York. Free Press.

Rangkuti, Freddy (2013). Analisis SWOT : Teknik Membedah Kasus. Jakarta. PT Gramedia Pustaka Utama.

Rangkuti, Freddy (2013). SWOT Balanced Scorecard : Teknik Menyusun Strategi Korporat yang Efektif Plus Cara Mengelola Kinerja dan Resiko. Jakarta. PT Gramedia Pustaka Utama.

Sekaran, Uma (1992). Research Methods for Business: A Skill Building Approach, 2nd.ed. New York. Jhon Wiley and Sons.

Siahaan, Uke (2013). Materi Ajar Strategi Keuangan Magister Administrasi Bisnis. Malang. Universitas Brawijaya.
Solihin, Ismail (2012). Manajemen Strategik. Bandung. Erlangga.

Syamsuddin, Lukman (2004). Manajemen Keuangan Perusahaan, Konsep Aplikasi Dalam : Perencanaan, Pengawasan, dan Pengambilan Keputusan. Jakarta. PT Raja Grafindo Persada.

Waterman, Robert Jr,.(1982). The Renewal Factor: How The Best Get and Keep The Competitive Edge. Bussines Week:12

Walsh, Ciaran (2012). Key Management Ratios, Edisi 4. Jakarta. Erlangga

Welsh, A. Dkk. (1998). Budgeting: Profit Planning and Control, Edisi 5. New Jersey. Pearson, Prentice Hall.

http://www.bi.go.id.

http://www.bps.go.id/hasil publikasi/stat kela pa sawit 2013/index3.php?pub=Statis tik\%20Kelapa\%20Sawit\%202013

http://www.bps.go.id/hasil_publikasi/dir_kelap a_sawit_2013/index3.php?pub=Direkt ori\%20Perusahaan\%20Perkebunan $\% 2$ 0Kelapa\%20sawit\%20Indonesia\%202 $\underline{013}$

http://www.industri.kontan.co.id/news/wilmarmenang-tender-biodiesel

http://www.kemenkeu.go.id/berita/pertumbuha $\underline{\text { n-ekonomi-2014 }}$

http://www.ptpn3.co.id

http://www.regionalinvestment.bkpm.go.id/

http://www.simedarby.com/upload/Palm Oil Facts and Figures.pdf.

http://www.wapresri.go.id. 